\title{
Motivasi anggota dan peran Tim Reaksi Cepat (TRC) dalam bekerja di Badan Penanggulangan Bencana Daerah (BPBD) Kabupaten Ponorogo
}

\author{
Aam Amelia Agustin \\ Institut Agama Islam Negeri (IAIN) Ponorogo \\ Kayyis Fithri Ajhuri \\ Institut Agama Islam Negeri (IAIN) Ponorogo
}

\begin{abstract}
ABSTRAK
Salah satu pekerjaan di Kabupaten Ponorogo yang mengandung unsur kesempatan, tantangan, dan harapan adalah menjadi anggota dari Tim Reaksi Cepat (TRC) BPBD Kabupaten Ponorogo. Tim ini bekerja dalam bidang sosial kebencanaan yang memiliki kekhasan yaitu beranggotakan relawan yang berjiwa sosial yang tinggi dan memiliki keahlian dalam penyelamatan. Waktu bekerja berkaitan dengan kejadian bencana, kondisi fisik dan psikis yang kuat dan baik, tanggungjawab atas keselamatan orang lain dan risiko besar dan berat di medan saat terjadinya bencana mengiringi pelaksanaan tugas dalam bekerja bagi TRC. Penelitian ini memiliki tujuan yang menjawab rumusan masalah yaitu untuk mengetahui motivasi anggota TRC dalam bekerja, peran TRC bekerja di BPBD Kabupaten Ponorogo, dan motivasi anggota TRC berlaku dalam pelaksanaan peran dari TRC di BPBD Kabupaten Ponorogo. Metode penelitian yang digunakan adalah kualitatif deskriptif dengan teknik pengumpulan data menggunakan observasi, wawancara, dan dokumentasi. Subjek penelitian adalah 20 anggota TRC dengan sampel berdasarkan purposive sampling yang berjumlah 2 anggota laki-laki belum menikah dan 2 anggota laki-laki sudah menikah dari 20 jumlah seluruh anggota TRC BPBD Kabupaten Ponorogo.

Hasil analisis pada motivasi anggota TRC BPBD Kabupaten Ponorogo dalam bekerja menggunakan Teori Dua Faktor Frederick Hezberg adalah motivasi anggota TRC dalam bekerja terdiri dari motivasi intrisik berupa keinginan, memiliki skill atau keahlian dalam penyelamatan, dan keyakinan diri. Motivasi ekstrinsik berupa dukungan dari orang lain dan motivasi dari BPBD Kabupaten Ponorogo yang terdiri dari: gaji, pengakuan dan pendampingan kerja, jam kerja, Markas komando (Mako), dan penyampaian aspirasi.

Peran TRC di BPBD Kabupaten Ponorogo adalah pada pelaksanaan penggalian informasi untuk pengkajian cepat di lokasi kejadian saat terjadi bencana dan penambahan personel. Dengan motivasi bekerja tersebut
\end{abstract}


menghasilkan rasa kepuasan dan senang bagi anggota TRC. Anggota TRC dapat membantu sesama manusia yang membutuhkan pertolongan pada kebencanaan. Sehingga pelaksanaan peran TRC di BPBD Kabupaten Ponorogo berupa kaji cepat dan penanganan bencana serta menambah jumlah personel dari BPBD Kabupaten Ponorogo dapat berjalan dengan baik.

\section{Kata Kunci: Motivasi, Bekerja, Peran, TRC, Bencana, Tim Reaksi Cepat.}

\section{PENDAHULUAN}

TRC BPBD Kabupaten Ponorogo ini bekerja dalam penanganan bencana yang terjadi, khususnya yang berada di Kabupaten Ponorogo. Tim ini adalah sebuah tim dengan pekerjaan yang membutuhkan fisik kuat, psikis kuat, serta jiwa untuk kemanusiaan atau jiwa relawan yang besar. Untuk memudahkan memahami mengenai TRC BPBD Kabupaten Ponorogo yaitu bahwa tim ini adalah sebuah tim yang dibentuk secara khusus untuk melakukan pengkajian cepat mengenai beberapa hal berkaitan pada saat terjadinya bencana.

Bencana adalah peristiwa atau rangkaian peristiwa yang mengancam dan mengganggu kehidupan dan penghidupan masyarakat yang disebabkan, baik oleh faktor alam dan/atau faktor nonalam maupun faktor manusia sehingga mengakibatkan timbulnya korban jiwa manusia, kerusakan lingkungan, kerugian harta benda, dan dampak psikologis. ${ }^{1}$ Penanggulangan bencana yang dilakukan oleh BPBD Kabupaten Ponorogo termasuk di dalamnya dilakukan oleh TRC seperti bencana kekeringan, hujan yang menyebabkan luapan air, longsor, banjir, penyakit demam berdarah pasca bencana, angin yang menimpa fasilitas umum, dan laka air seperti orang hanyut dan penemuan korban di dalam sumur.

Selain memiliki risiko yang besar, anggota TRC sebisa mungkin harus on call atau siap sedia kapanpun dibutuhkan. Hal ini karena bencana dapat terjadi kapan saja. Anggota TRC harus siap di segala waktu untuk turun langsung di lokasi terjadi kejadian bencana guna melakukan pengkajian cepat. Pengkajian

1 Pengertian Bencana, Peraturan Kepala Badan Nasional Penanggulangan Bencana Nomor 3 Tahun 2008 Tentang Pedoman Pembentukan Badan Penanggulangan Bencana Daerah, 2. 
cepat yang dilakukan TRC inilah yang selanjutnya digunakan untuk menentukan langkah tidak lanjut pada sebuah kejadian bencana.

Relawan pada umumnya yang diketahui oleh masyarakat adalah relawan yang hanya akan muncul pada saat terjadi hal-hal darurat seperti bencana atau bisa disebut secara insidental. Pekerjaan ini tidak mudah dan memiliki risiko sekaligus tanggungjawab yang besar untuk siap siaga setiap saat. Selain itu dengan status usia yang berbeda-beda tentu saja motivasi yang muncul dalam bekerja dan melakukan tugas sebagai anggota tim ini juga berbeda-beda.

TRC BPBD Kabupaten Ponorogo berada di lokasi bencana saat terjadinya bencana. TRC memiliki peran penting karena melalui tim ini dapat ditentukan tindak lanjut dalam penanganan bencana yang terjadi. Selain itu TRC BPBD Kabupaten Ponorogo belum banyak diketahui oleh khalayak umum. Seragam oranye dikenal sebagai ciri khas BPBD menjadi tanda bahwa tim tersebut datang dari BPBD Kabupaten Ponorogo.

Rumusan masalah dalam penelitian ini adalah bagaimana motivasi anggota dan peran TRC dalam bekerja di BPBD Kabupaten Ponorogo?. Tujuan penelitian ini adalah untuk mengetahui motivasi anggota dan peran TRC dalam bekerja di BPBD Kabupaten Ponorogo.

\section{METODE PENELITIAN}

Penelitian ini menggunakan metode penelitian kualitatif dengan jenis penelitian deskriptif. Penelitian kualitatif adalah penelitian yang bermaksud untuk memahami fenomena tentang apa yang dialami oleh subjek penelitian misalnya perilaku, persepsi, motivasi, tindakan, dan lain-lain secara holistik dan dengan cara deskripsi dalam bentuk kata-kata dan bahasa, pada suatu konteks khusus yang alamiah dan dengan memanfaatkan berbagai metode alamiah. ${ }^{2}$ Penelitian ini bertujuan untuk mendeskripsikan suatu fenomena tanpa melakukan intervensi atau treatment.

\footnotetext{
${ }^{2}$ Lexy J. Moleong, Metodologi Penelitian Kualitatif, (Bandung: PT Remaja Rosdakarya,
} 2016), 6 . 
Dalam penelitian ini, lokasi yang digunakan adalah Badan Penanggulangan Bencana Daerah (BPBD) Kabupaten Ponorogo yang berada di Jalan Sekar Putih Timur No. 32 Tonatan Kecamatan Ponorogo Kabupaten Ponorogo. Penelitian dilaksanakan pada tanggal 1 sampai dengan 31 Maret 2020.

Subjek dari penelitian ini adalah anggota TRC BPBD Kabupaten Ponorogo. Jumlah anggota TRC secara keseluruhan adalah 20 orang yang terdiri dari 16 anggota laki-laki dan 4 anggota perempuan. ${ }^{3}$ Sampel subjek penelitian ini dipilih dengan purposive sampling. Purposive sampling adalah teknik pengambilan sampel sumber data dengan pertimbangan tertentu. ${ }^{4}$ Sampel subjek penelitian sekaligus sebagai sumber data adalah beberapa anggota laki-laki sesuai dengan pertimbangan dengan status belum dan sudah menikah. Pertimbangan tersebut digunakan untuk melihat adanya perbedaan atau persamaan motivasi kerja.

Sumber data juga didapatkan dari Kepala Bidang (Kabid) dan Kepala Seksi (Kasi) Bidang Kedaruratan dan Logistik, Kasubag Umum dan Kepegawaian, regulasi atau peraturan dari pemerintah, data informasi mengenai TRC BPBD Kabupaten Ponorogo berupa jadwal piket TRC dan Pusdalops PB Bulan Maret 2020.

Beberapa kegiatan yang diobservasi adalah kegiatan TRC saat berada di Markas Komando (Mako) selama rentang waktu penelitian, kegiatan TRC saat berada di lokasi pengungsian korban tanah longsor di Desa Dayakan Kecamatan Badegan, dan kegiatan penyemprotan pembersihan satu ruas jalan di Desa Brahu Kecamatan Siman Kabupaten Ponorogo.

Kegiatan wawancara yang dilakukan dengan Kasi Bidang Kedaruratan dan Logistik dengan topik wawancara penanganan bencana oleh TRC BPBD Kabupaten Ponorogo. Wawancara dengan Kabid Kedaruratan dan Logistik mengenai topik tentang TRC, tugas dan peran TRC. Wawancara dengan empat anggota TRC sebagai sampel subjek penelitian dengan topik wawancara motivasi dalam bekerja bagi anggota TRC belum dan sudah menikah. Selain itu peneliti

3 Jadwal Piket Harian Mako Tim Reaksi Cepat (TRC) Dan Pusdalops Badan Penanggulangan Bencana Daerah Kabupaten Ponorogo Bulan Maret 2020.

${ }^{4}$ Sugiyono, Metode Penelitian Kuantitatif, Kualitatif, dan R\&D, (Bandung: CV Alfabeta, 2016), 218-219. 
juga melakukan wawancara dengan Kasubag Umum dan Kepegawaian dengan topik wawancara mengenai TRC di BPBD Kabupaten Ponorogo.

a. Dokumentasi. Dokumentasi berupa foto yang diambil oleh peulis sendiri dan foto yang didapatkan dari anggota TRC. Foto-foto yang dimaksud adalah foto kegiatan TRC dalam tugas pendistribusian air bersih; tugas dalam bencana tanah longsor seperti pengecekan retakan tanah, mapping atau pemetaan; penyemprotn ruas jalan akibat banjir; Markas komando atau Mako TRC BPBD Kabupaten Ponorogo, dan proses wawancara bersama dengan Kepala Bidang Kedaruratan dan Logistik dan Kasubag Umum dan Kepegawaian.

Peneliti menggunakan teknik analisis data menurut Miles dan Huberman yaitu reduction, display data, dan conclusion drawing/verification. ${ }^{5}$

a. Reduction atau data reduction yaitu mereduksi data berarti merangkum, memilih hal-hal yang pokok, memfokuskan pada hal-hal yang penting, dicari tema dan polanya.

b. Data display atau penyajian data yang paling sering digunakan untuk menyajikan data dalam penelitian kualitatif adalah teks yang bersifat naratif. Penyajian data berupa teks naratif deskriptif.

c. Conclusion drawing/verification yaitu penarikan kesimpulan dan verifikasi. Penarikan kesimpulan ini didapatkan dari data yang telah disajikan hasil dari penyajian data yang telah berfokus pada tujuan penelitian.

Triangulasi yang dilakukan dalam penelitian ini adalah triangulasi sumber dan triangulasi teknik. Triangulasi sumber dilakukan dengan cara mengecek data yang telah diperoleh melalui beberapa sumber. Sedangkan triangulasi teknik dengan cara mengecek data kepada sumber yang sama dengan teknik yang berbeda. ${ }^{6}$

Pengecekan keabsahan temuan data menggunakan sumber data yang didapatkan di lapangan melalui wawancara dan pada regulasi atau peraturan pemerintah, jadwal piket TRC dan Pusdalops PB Bulan Maret 2020. Sedangkan

\footnotetext{
${ }^{5}$ Ibid., 246-252.

${ }^{6}$ Ibid., $273-274$.
} 
pengecekan pada teknik dengan mencek Kembali data kesamaan data yang didapatkan dari observasi, wawancara, dan dokumentasi.

Motivasi adalah proses memengaruhi atau mendorong dari luar terhadap seseorang atau kelompok kerja agar mereka mau melaksanakan sesuatu yang telah ditetapkan. Motivasi atau dorongan (driving force) dimaksudkan sebagai desakan yang alami untuk memuaskan dan mempertahankan kehidupan. Jadi motivasi kerja adalah sesuatu yang menimbulkan dorongan atau semangat kerja. Beberapa faktor yang dapat memengaruhi motivasi kerja, antara lain atasan, kolega, sarana fisik, kebijaksanaan, peraturan, imbalan jasa uang dan non-uang, jenis pekerjaan, dan tantangan. Motivasi individu untuk bekerja dipengaruhi pula oleh kepentingan pribadi dan kebutuhannya masing-masing. ${ }^{7}$

\section{Teori Motivasi: Teori Dua Faktor Frederick Hezberg}

Hezberg dalam Malayu S.P. Hasibuan menyatakan bahwa orang dalam melaksanakan pekerjaannya dipengaruhi oleh dua faktor yang merupakan kebutuhan. ${ }^{8}$

\section{a. Maintenance Factors}

Maintenance factors adalah faktor-faktor pemeliharaan yang berhubungan dengan hakikat manusia yang ingin memperoleh ketenteraman badaniah. Kebutuhan kesehatan ini menurut Hezberg merupakan kebutuhan yang berlangsung terus-menerus, karena kebutuhan ini akan kembali pada titik nol setelah dipenuhi. Misalnya orang lapar akan makan, kemudian lapar lagi, lalu makan lagi, dan seterusnya.

Faktor-faktor pemeliharaan ini meliputi hal-hal gaji, kondisi kerja fisik, kepastian pekerjaan, supervisi yang menyenangkan, mobil dinas, rumah dinas, dan macam-macam tunjangan lainnya. Hilangnya faktor-faktor pemeliharaan ini dapat menyebabkan timbulnya ketidakpuasan dan absennya karyawan, bahkan dapat menyebabkan banyak karyawan keluar. Maintenance factors ini bukanlah

${ }^{7}$ Sadili Samsudin, Manajemen Sumber Daya Manusia (Bandung: CV Pustaka Setia, 2006), 281-282.

${ }^{8}$ Malayu S.P. Hasibuan, Manajemen: Dasar, Pengertian, dan Masalah (Jakarta: PT Bumi Aksara, 2016), 228. 
merupakan motivasi bagi karyawan, tetapi merupakan keharusan yang harus diberikan oleh pimpinan kepada mereka, demi kesehatan dan kepuasan bawahan. Menurut Hezberg, maintenance factors bukan alat motivator sedangkan menurut Maslow merupakan alat motivator bagi karyawan.

b. Motivation Factors

Motivation factors adalah faktor motivator yang menyangkut kebutuhan psikologis seseorang yaitu perasaan sempurna dalam melakukan pekerjaan. Faktor motivasi ini berhubungan dengan penghargaan terhadap pribadi yang secara langsung berkaitan dengan pekerjaan, misalnya kursi yang empuk, ruangan yang nyaman, penempatan yang tepat, dan lain sebagainya. ${ }^{9}$

Konsep higiene juga disebut teori dua faktor, yaitu:

1) Isi (content $=$ satisfiers) pekerjaan

a) Prestasi (achievement)

b) Pengakuan (recognition)

c) Pekerjaan itu sendiri (the work itself)

d) Tanggungjawab (responbility)

e) Pengembangan potensi individu (advancement) Rangkaian ini melukiskan hubungan seseorang dengan apa yang dikerjakannya (job content) yakni kandungan kerja pada tugasnya.

2) Faktor higienis (demotivasi $=$ dissatisfiers)

a) Gaji atau upah (wages or salaries)

b)Kondisi kerja (working condition)

c) Kebijaksanaan dan administrasi perusahaan (company policy and administration)

d)Hubungan antarpribadi (interpersonal relation)

e) Kualitas supervise (quality supervisor)

Hezberg dalam Manahan P. Tampubolon (2015) disebutkan telah mengembangkan Teori Dua Faktor tentang motivasi yaitu faktor yang membuat orang merasa puas dan yang membuat tidak puas (ekstrinsik dan intrinsik) yang dikenal sebagai Teori Higieni Motivasi (Motivation Hygiene Theory). Penelitian

\footnotetext{
${ }^{9}$ Ibid., 228-229.
} 
yang dilakukan oleh Hezberg melahirkan dua kesimpulan mengenai teori tersebut. Penjelasan di bawah ini sebagai berikut. ${ }^{10}$

Pertama, ada serangkaian kondisi ekstrinsik, yaitu keadaan pekerjaan dan hygienic yang menyebabkan rasa tidak puas diantara para karyawan apabila kondisi ini tidak ada sehingga tidak perlu memotivasi karyawan. Sebaliknya apabila keadaan pekerjaan dan hygienic cukup baik, keadaan ini dapat membentuk kepuasan bagi karyawan. Faktor-faktor itu meliputi upah, keamanan kerja, kondisi kerja dan hygienic, status, prosedur perusahaan, mutu dari supervisi teknis, dan mutu dari hubungan interpersonal di antara teman sejawat, baik atasan maupun bawahan.

Kedua, serangkaian kondisi intrinsik, yaitu apabila terdapat dalam pekerjaan maka akan menggerakkan tingkat motivasi yang kuat, sehingga menghasilkan prestasi pekerjaan yang baik. Jika kondisi ini tidak ada, maka tidak menimbulkan rasa ketidakpuasan yang berlebihan, yang meliputi prestasi (achievement), pengakuan (recognition), tanggungjawab (responbility), kemajuan (advancement), pekerjaan itu sendiri (the work itself), dan kemungkinan berkembang (the possibility of growth).

2. Kerja

Definisi atau istilah kerja dalam budaya organisasi dilakukan dengan mengidentifikasi dan mempunyai arti sebagai berikut. ${ }^{11}$

a. Kerja adalah sumber penghasilan, hal ini jelas kerja sebagai sumber nafkah merupakan anggaran dasar masyarakat umumnya.

b. Kerja adalah kesenangan, kerja sebagai kesenangan seakan hobi, karena suka kerja workaholic).

c. Kerja adalah aktualisasi diri, kerja disini dikaitkan dengan peran, cita-cita atau ambisi (ibaratnya, lebih memilih jadi kepala ayam daripada ekor sapi).

d. Kerja adalah panggilan jiwa, kerja disini berkaitan dengan bakat, disini tumbuh profesionalisme dan pengabdian kepada kerja.

${ }^{10}$ Manahan P. Tampubolon, Perilaku Keorganisasian (Organization Behavior) (Bogor: Ghalia Indonesia, 2015), 92-93.

11 Moeheriono, Pengukuran Kinerja Berbasis Kompetensi (Jakarta: PT Rajagrafindo Persada, 2012), 350. 
e. Kerja adalah pengabdian kepada sesama, kerja dilakukan dengan tulus dan tanpa pamrih.

f. Kerja adalah ibadah, kerja sebagai pernyataan syukur atas kehidupan di dunia ini, dilakukan seakan-akan kepada dan bagi kemuliaan nama Tuhan bukan kepada manusia.

g. Kerja adalah suci, kerja harus dihormati dan jangan dicemarkan dengan perbuatan dosa pelanggaran dan kejahatan.

\section{A. Peranan (Role)}

Peranan (role) merupakan aspek dinamis kedudukan (status). Apabila seseorang melasanakan hak dan kewajibannya sesuai dengan kedudukannya, dia menjalankan suatu peranan. Pembedaan antara kedudukan dengan peranan adalah untuk kepentingan ilmu pengetahuan. Keduanya tak dapat dipisah-pisahkan karena yang satu tergantung pada yang lain dan sebaliknya. Tak ada peranan tanpa kedudukan atau kedudukan tanpa peranan. Sebagaimana halnya dengan kedudukan, peranan juga mempunyai dua arti. ${ }^{12}$

Setiap orang mempunyai macam-macam peranan yang berasal dari polapola pergaulan hidupnya. Hal itu sekaligus berarti bahwa peranan menentukan apa yang diperbuatnya bagi masyarakat serta kesempatan-kesempatan apa yang diberikan oleh masyarakat kepadanya. Pentingnya peranan adalah karena ia mengatur perilaku seseorang. Peranan menyebabkan seseorang pada batas-batas tertentu dapat meramalkan perbuatan-perbuatan orang lain. ${ }^{13}$

\section{HASIL PENELITIAN DAN PEMBAHASAN}

Dalam penelitian ini, sampel subjek penelitian yaitu anggota TRC yaitu Danang Wisnu Saifudin berusia 24 tahun, Rizal Prasetya berusia 25 tahun, Hadi Susanto berusia 36 tahun, dan Suwito berusia 40 tahun. Beberapa anggota TRC BPBD Kabupaten Ponorogo ini berada pada rentang usia dewasa dini dan dewasa madya. Dengan melihat tugas-tugas perkembangan telah disebutkan di paparan

${ }^{12}$ Soerjono Soekanto dan Budi Sulistyowati, Sosiologi Suatu Pengantar (Jakarta: PT Rajagrafindo Persada, 2015), 210-211.

${ }^{13}$ Ibid., 211. 
Kajian Teori, kaitannya dengan anggota TRC yaitu dalam pekerjaan, karier, minat, aktifitas sosial, dan penyesuaian diri. Selain itu juga dalam berkeluarga, peneliti menggunakan status pernikahan sebagai kriteria pemilihan sampel subjek penelitian. Hal ini akan berkaitan dengan motivasi seseorang yang memiliki tanggungjawab sebagai kepala keluarga bagi yang sudah menikah yaitu anggota TRC dalam bekerja.

Hasil analisis dari peneliti adalah antara anggota TRC laki-laki yang belum dan sudah menikah tidak terdapat perbedaan motivasi yang besar. Baik anggota yang belum maupun sudah menikah dalam bekerja mendapatkan porsi piket yang sama, menjalani aturan yang sama, menjalankan tugas yang sama, dan mendapatkan treatment atau perlakukan yang sama dari BPBD Kabupaten Ponorogo. Sehingga motivasi dari masing-masing anggota sejalan berkaitan dengan tugas-tugas perkembangan pada tahap dewasa dini dan dewasa madya.

Meskipun demikian tetap terdapat perbedaan. Perbedaan anggota TRC yang belum dan sudah menikah terletak pada cara anggota TRC tersebut mengelola waktu untuk pekerjaan sebagai TRC dan untuk keluarga inti mereka. Sebagai kepala keluarga, anggota TRC memiliki kewajiban untuk berfokus pada istri dan anak. Sedangkan bagi anggota yang belum menikah, maka belum menjadi seorang kepala keluarga sehingga pengelolaan waktu dan kewajiban serta tanggungjawab belum untuk istri dan anak.

1. Motivasi anggota TRC dalam bekerja di BPBD Kabupaten Ponorogo

Hasil analisis mengenai motivasi anggota TRC bekerja di TRC BPBD Kabupaten Ponorogo menggunakan teori ini adalah konsep higiene bahwasanya motivasi anggota TRC BPBD Kabupaten Ponorogo dalam bekerja terdiri dari motivasi intrinsik dan ekstrinsik. Motivasi anggota TRC dalam bekerja di TRC BPBD Kabupaten Ponorogo adalah sebagai berikut:

a. Motivasi intrinsik

Motivasi intrinsik yaitu motivasi berupa dorongan dan keinginan yang berasal atau muncul dari dalam diri seseorang itu sendiri.

1) Keinginan 
Keinginan yang dimiliki oleh anggota TRC mendorong untuk melakukan sebuah tindakan. Tindakan tersebut adalah dalam bekerja di TRC BPBD Kabupaten Ponorogo.

a) Para anggota memiliki hati nurani karena merasa dirinya dibutuhkan saat orang lain membutuhkan.

b) Penyaluran atau perwujudan dari jiwa sosial yang dimiliki oleh anggota TRC.

c) Adanya harapan apabila pada suatu saat anggota keluarga dari anggota TRC membutuhkan maka akan ada yang membantu.

d) Keinginan untuk menolong sesama makhluk ciptaan Allah SWT.

2) Memiliki keahlian atau skill dalam penyelamatan

Skill atau keahlian yang dimiliki oleh anggota TRC berupa vertical rescue, jungle rescue, armada atau transportasi, komunikasi, penanganan pada mayat, assessment, dan navigasi darat. Namun hal ini tidak menutup kemungkinan para anggota TRC memiliki keahlian yang lain. Berbagai keahlian tersebut menjadikan proses pengkajian cepat dan penanganan termasuk proses evakuasi lebih cepat sesuai komando dan kerja sama tim.

3) Keyakinan diri

Berikut cara anggota TRC meyakinkan diri dapat menyelesaikan pekerjaan. a) Melakukan pekerjaan dengan ikhlas yang menjadikan percaya diri dapat menyelesaikan setiap pekerjaan di TRC. b) Menguatkan niat yang dimiliki untuk membantu masyarakat yang membutuhkan bantuan dan setelah itu melihat senyuman dari masyarakat yang dapat mendatangkan kepuasan. c)Meyakini bahwa ada jalan dari Allah SWT selama memiliki niat baik untuk menjalankan tugas dalam pekerjaan di TRC. d)Menyadari kemampuan yang dimiliki oleh diri sendiri untuk mementingkan kebutuhan orang lain.

b. Motivasi ekstrinsik

1) Dukungan dari orang lain

Dukungan dari pihak lain selain diri sendiri turut memotivasi anggota dalam bekerja. Hal yang dapat menambah semangat bekerja bagi anggota TRC adalah merasa belum puas apabila belum menolong orang lain; adanya dukungan tim dengan para anggota saling mendukung satu sama lain; dukungan orang sekitar 
yaitu orang tua, istri, anak, teman, sahabat; dan dukungan masyarakat khususnya yang berada di Kabupaten Ponorogo.

Dukungan dari istri yang besar dapat menambah dorongan semangat bagi anggota TRC dalam bekerja. Selain itu juga dibutuhkan penyesuaianpenyesuaian yang lain yang dalam kenyataannya hubungan suami istri, hubungan orang tua dan anak, hubungan dengan sesama anggota keluarga yang lain tetap terjaga sesuai dengan kedudukannya dalam keluarga tersebut. Hubunganhubungan tersebut dapat berhasil dilakukan oleh anggota TRC yang sudah menikah dengan berusaha tetap menyesuaikan diri dan mengelola waktu sebaik mungkin. Sehingga baik pekerjaan, tanggungjawab, dan peran sebagai anggota TRC dan kepala keluarga tetap berjalan berdampingan.

2) Motivasi dari BPBD Kabupaten Ponorogo

a) Gaji

Gaji yang didapatkan masih di bawah UMK (Upah Minimum Kabupaten/Kota) Kabupaten Ponorogo yang berjumlah Rp 1.913.321,73. Hal ini apabila dilihat dari Keputusan Gubernur Jawa Timur Nomor 188/568/KPTS/013/2019 tentang Upah Minimum Kabupaten/Kota di Jawa Timur Tahun 2020. ${ }^{14}$

Bagi anggota TRC, gaji atau upah bukanlah satu-satunya tujuan utama dalam bekerja. Meskipun demikian, para anggota TRC merasa cukup dengan gaji tersebut. Gaji merupakan salah satu pendorong sehingga anggota menghasilkan kinerja yang sesuai yang diharapkan dari adanya TRC di BPBD Kabupaten Ponorogo.

b) Pengakuan dan pendampingan kerja

Anggota TRC berawal dari relawan-relawan bencana dari berbagai komunitas sosial dan komunitas bencana yang berhubungan baik dengan BPBD Kabupaten Ponorogo. Dengan adanya TRC ini, anggota sebagai relawan diakoomodir kerjanya dan mendapat pengakuan sebagai bagian dari BPBD Kabupaten Ponorogo. Fasilitas yang diberikan berupa alat-alat kerja, hal-hal lain yang

${ }^{14}$ Upah Minimum Kabupaten/Kota di Jawa Timur, Keputusan Gubernur Jawa Timur Nomor 188/568/KPTS/013/2019 tentang Upah Minimum Kabupaten/Kota di Jawa Timur Tahun 2020, lampiran 2. 
mendukung kelancaran kerja (seperti wifi, konsumsi), sarana dan prasarana dan seragam kerja. Peralatan maupun sarana dan prasarana untuk penanganan bencana mempercepat tindakan proses evakuasi. Seragam kerja bagi TRC juga menjadi sebuah ciri khas utama bagi para anggota yang berkaitan dengan pengakuan atau tanda pada dirinya sebagai anggota TRC yang menjadi bagian dari badan pemerintahan, yaitu BPBD Kabupaten Ponorogo.

Pendampingan kerja yang dilakukan dengan cara datang bersama anggota TRC pada kejadian bencana. Pendampingan keja dilakukan oleh atasan TRC yaitu Kasi ataupun Kabid pada saat TRC menjalankan tugas. Hal ini menunjukkan bahwa tidak hanya komando yang diberikan namun juga dengan tindakan nyata dari atasan. Pendampingan ini menghasilkan perhatian dan dorongan dukungan untuk anggota TRC. Sehingga para anggota menjadi lebih semangat dan terdorong untuk lebih giat dalam pelaksaan tugas TRC.

c) Jam kerja

Jam kerja bagi TRC berupa adanya jadwal piket dengan pembagian piket pagi, piket siang, piket malam, dan piket on call. Jadwal piket ini untuk 20 anggota TRC dan 4 tenaga Pusdalops PB yang terbagi menjadi 4 tim piket. Setiap tim piket terdiri dari 5 anggota TRC dan 1 tenaga Pusdalops PB. Jam kerja ini berlaku untuk seluruh anggota TRC tanpa membedakan status pernikahan. Namun dalam hal ini, para anggota dapat tetap stay atau hadir di Mako meskipun bukan saat jam piket.

d) Markas Komando (Mako) TRC di BPBD Kabupaten Ponorogo

Selama waktu piket, anggota TRC menempati Mako yaitu Markas Komando yang berada di belakang bangunan utama kantor BPBD Kabupaten Ponorogo. Para anggota dapat melakukan perawatan peralatan-peralatan dan sarpras untuk penanganan bencana.

Berikut di bawah ini pendapat anggota TRC mengenai Mako TRC BPBD Kabupaten Ponorogo saat ini.

(1) Mako tersebut nyaman dan dirasa asyik dengan suasana tim yang kompak dan saling menyemangati.

(2) Mako sudah mengalami banyak perubahan dari yang dulu hingga saat ini. 
(3) Adanya harapan untuk Mako dapat lebih nyaman, yaitu adanya penambahan peralatan seperti tempat untuk istirahat dan papan untuk pelatihan vertical rescue, adanya harapan peningkatan Mako, seperti dibuatkan tempat yang terbuka namun menjadi tempat khusus bagi TRC dari mulai administrasi, penyimpanan alat dan sarpras, perawatan alat evakuasi, lab jaket, sepatu, pelampung, sehingga dapat terlindungi dengan baik.

e) Penyampaian aspirasi

Penyampaian keluhan atau masukan dari anggota TRC kepada atasan menurut anggota selama ini dilakukan secara komunikatif. Selain itu juga saling terbuka dan adanya koordinasi dengan staf, Kasi, Kabid Kedaruratan dan Logistik dengan baik. Misalnya terdapat forum evaluasi untuk mendiskusikan kinerja, keluhan, kekurangan, dan masukan.

Motivasi intrinsik dan motivasi ekstrinsik anggota TRC BPBD Kabupaten Ponorogo seperti yang telah dipaparkan di atas memenuhi maintenance factors dan motivation factors pada Teori Dua Faktor Hezberg. Motivasi ekstrinsik berupa dukungan dari pihak lain dan motivasi yang diberikan dari BPBD Kabupaten Ponorogo berupa gaji, pengakuan dan pendampingan kerja, jam kerja, Markas komando atau Mako, dan penyampaian aspirasi mampu menunjang dan mendukung munculnya pemenuhan kepuasan bagi anggota TRC BPBD Kabupaten Ponorogo dalam bekerja.

Hal-hal tersebut di atas melengkapi pelaksanaan tugas dan peran TRC dalam bekerja. Keinginan anggota TRC untuk selalu menolong orang lain dalam suatu kejadian bencana telah selesai kemudian muncul bencana lain sehingga terdapat komando tugas yang kembali ke titik nol untuk dilakukan TRC BPBD Kabupaten Ponorogo. Penggunaan jam kerja dan Mako secara terus-menerus. Gaji yang menjadi alat pemenuh kebutuhan hidup akan kembali ke titik nol setelah terpenuhi. Selain itu pemanfaatan penyampaian aspirasi dari anggota TRC yang dapat dilakukan secara fleksibel, terbuka, dan komunikatif.

Pada motivation factors, hal-hal berlaku untuk menekan rasa ketidakpuasan. Motivasi intrinsik berupa keinginan, skill penyelamatan pada bencana, dan keyakinan diri pada tugas kerja yang dilakukan mampu memunculkan kepuasan 
dan rasa senang bagi anggota TRC BPBD Kabupaten Ponorogo. Pada dasarnya pemenuhan kepuasan dari motivasi intrinsik juga sangat dipengaruhi oleh motivasi ekstrinsik. Hal ini karena di dalam bekerja dibutuhkan komando, peralatan dan perlengkapan, pembagian tugas melalui koordinasi yang baik dengan saling mendukung bagi sesama anggota TRC dan dari pihak lain pada suatu kejadian bencana. Sehingga keinginan, skill penyelamatan, dan keyakinan diri anggota TRC dapat terwujud.

Keinginan menolong orang lain dalam bencana sebagai relawan telah menjadi titik tolak para anggota sebelum bergabung menjadi anggota TRC BPBD Kabupaten Ponorogo. Dengan bergabung di TRC, pelaksanaan tugas sebagai relawan menjadi terakoomodir baik waktu, koordinasi, dan komando tugas karena ada BPBD Kabupaten Ponorogo secara langsung yang memberikan komando yaitu melalui Kabid Kedaruratan dan Logistik BPBD Kabupaten Ponorogo. Adanya perlengkapan penanggulangan bencana dari BPBD Kabupaten Ponorogo sendiri dapat memperlancar proses evakuasi dan penanganan bencana. Anggota TRC mendapatkan rasa puas dan senang dengan pekerjaan yang dilakukan.

\section{A. Peran Tim Reaksi Cepat (TRC) dalam Bekerja di BPBD Kabupaten Ponorogo}

Peran TRC BPBD Kabupaten Ponorogo sesuai dengan penuturan Kabid Kedaruratan dan Logistik selaku atasan langsung dari TRC bahwasannya peran TRC dalam bekerja di BPBD Kabupaten Ponorogo mengacu pada tupoksi atau tugas pokok dan fungsi TRC pada Peraturan Kepala BNPB. Tugas pokok dan fungsi TRC lebih tepatnya terdapat di Peraturan Kepala Badan Nasional Penanggulangan Bencana Nomor 9 Tahun 2008 Tentang Prosedur Tetap Tim Reaksi Cepat Badan Nasional Penanggulangan Bencana Bab II Tugas dan Pokok dan Fungsi TRC BNPB.

Dari paparan di atas mengenai peran TRC yang sesuai dengan tupoksi atau Tugas Pokok dan Fungsi pada Peraturan Kepala BNPB tentang TRC, sebagai berikut:

1. Pelaksanaan pengkajian cepat di lokasi kejadian bencana. 
TRC BPBD Kabupaten Ponorogo tiba lebih dulu di lokasi kejadian pada saat terjadinya bencana. Hal yang dilakukan adalah menggali informasi-informasi awal saat terjadi kejadian bencana dengan melakukan pencatatan informasi kronologis kejadian, lokasi, kerusakan, dan kebutuhan-kebutuhan yang dibutuhkan di lokasi terjadinya bencana. Hasil dari kaji cepat kejadian bencana selanjutnya dikaji di Bidang Kedaruratan dan Logistik BPBD Kabupaten Ponorogo untuk ditentukan dan dipersiapkan kebutuhan yang dibutuhkan di lokasi kejadian bencana. Dalam hal ini juga memungkinkan adanya koordinasi dengan pihak-pihak lain. Pihak-pihak lain tersebut seperti seperti organisasi-organisasi relawan untuk penambahan personel; masyarakat; satuan dinas pemerintahan seperti Dinas Sosial, Dinas Kesehatan, dan lain sebagainya; pihak lain yang berhubungan atau berkaitan dengan lokasi kejadian dan/atau penanganan penanggulangan kejadian bencana.

2. TRC BPBD Kabupaten Ponorogo menambah jumlah personel dari BPBD Kabupaten Ponorogo untuk lebih cepat penanganan dalam kejadian bencana.

Kerja TRC menambah percepatan pergerakan BPBD Kabupaten Ponorogo. Hal ini terwujud dalam peran tim pada kaji cepat dan penanganan kejadian bencana. Bencana dapat segera diketahui, dikaji, dan ditanggulangi karena anggota TRC menjalankan tugas sesuai dengan komando dari BPBD Kabupaten Ponorogo dan bersinergi bersama pihak penanggulangan bencana yang terjadi.

\section{B. Motivasi Anggota dan Peran Tim Reaksi Cepat (TRC) dalam Bekerja di BPBD Kabupaten Ponorogo}

Dengan melihat makna kerja yang tercantum pada Moeheriono (2012), motivasi berkaitan dengan peran kerja bagi anggota TRC BPBD Kabupaten Ponorogo dalam kejadian bencana sebagai berikut:

1. Kerja adalah sumber penghasilan. Anggota TRC BPBD Kabupaten Ponorogo mendapatkan gaji digunakan untuk memenuhi kebutuhan hidup baik bagi anggota yang belum maupun sudah menikah. Meskipun demikian, gaji bukan satu-satunya alasan atau pendorong utama bagi anggota untuk bekerja di TRC BPBD Kabupaten Ponorogo. 
2. Kerja adalah kesenangan. Anggota TRC memiliki keinginan yang kuat dan dengan senang hati melakukan pekerjaan tersebut.

3. Kerja adalah aktualisasi diri. Hal ini dilakukan dengan bekal komando langsung dari BPBD Kabupaten Ponorogo. Sehingga pekerjaan yang dilakukan atas dasar eksplorasi pada diri sendiri disertai keahlian atau skill untuk menjalankan tugas sesuai peran TRC di BPBD Kabupaten Ponorogo.

4. Kerja adalah panggilan jiwa, kerja. TRC BPBD Kabupaten Ponorogo untuk bekerja dalam penanganan bencana membutuhkan kekuatan fisik, hati nurani dengan jiwa sosial yang besar, kondisi psikis yang baik, dan skill penyelamatan yang baik dan benar.

5. Kerja adalah pengabdian kepada sesama. Wujud pengabdian atau bentuk nyata kerja anggota TRC dengan melakukan tugas berfokus pada terdampak bencana baik korban manusia maupun dampak fisik lainnya dengan kondisi sedemikian rupa.

6. Kerja adalah ibadah. Para anggota memahami bahwa dirinya bekerja di TRC BPBD Kabupaten Ponorogo atas dasar peduli sesama manusia terutama manusia yang membutuhkan bantuan pada kejadian bencana dan sesama makhluk Allah SWT yang lain.

Pekerjaan yang dipenuhi dengan makna sosial yang tinggi ini dilihat dari motivasi yang disebutkan di atas membuat masing-masing anggota TRC BPBD Kabupaten Ponorogo mendapatkan rasa kepuasan diri dan merasa senang serta nyaman. Perasaan-perasaan tersebut melahirkan kondisi psikis anggota TRC BPBD Kabupaten Ponorogo mampu bekerja di tim ini. Motivasi-motivasi tersebut mendorong anggota TRC untuk pelaksanaan tugas kerja pada kaji cepat dan penanganan kejadian bencana. Sehingga anggota TRC dapat mewujudkan peran dari TRC BPBD Kabupaten Ponorogo dengan baik dan maksimal.

\section{PENUTUP}

\section{A. Kesimpulan}


Adanya motivasi intrinsik dan ekstrinsik yang menjadi motivasi bagi anggota TRC. Motivasi intrinsik anggota TRC BPBD Kabupaten Ponorogo berupa keinginan, memiliki skill atau keahlian dalam penyelamatan, keyakinan diri. Sedangkan motivasi ekstrinsik bagi anggota TRC BPBD Kabupaten Ponorogo adalah dukungan dari orang lain dan motivasi dari BPBD Kabupaten Ponorogo yang terdiri dari: gaji, pengakuan dan pendampingan kerja, jam kerja atau jadwal piket, Markas komando (Mako), dan penyampaian aspirasi. Peran TRC dalam bekerja di BPBD Kabupaten Ponorogo mengacu pada Peraturan Kepala atau Perka Badan Nasional Penanggulangan Bencana Nomor 9 Tahun 2008 Tentang Prosedur Tetap Tim Reaksi Cepat Badan Nasional Penanggulangan Bencana Bab II Tugas dan Pokok dan Fungsi TRC BNPB. Jadi peran TRC bekerja di BPBD Kabupaten Ponorogo sebagai bagian dari BPBD yang bertugas lebih dulu berada di lokasi kejadian bencana untuk menggali informasi untuk keperluan kaji cepat bencana dan mnambah personel untuk mempercepat dalam menangani bencana dan kaji cepat. Untuk motivasi anggota TRC dalam kaitannya pelaksanaan peran TRC bekerja di BPBD Kabupaten Ponorogo adalah kerja sebagai sumber penghasilan, kesenangan, aktualisasi diri, panggilan jiwa, pengabdian kepada sesama, dan ibadah. Semua makna kerja tersebut menyertai anggota TRC dalam melaksanakan tugas kerja di bidang kebencanaan dan secara psikologis, anggota TRC mendapatkan kepuasan dan rasa senang. Sehingga motivasi-motivasi tersebut mendorong para anggota untuk bekerja dengan penuh keikhlasan. TRC menambah jumlah personel dari BPBD Kabupaten Ponorogo untuk melakukan penanganan kejadian bencana yang terjadi. Oleh karena itu motivasi-motivasi tersebut mendorong anggota TRC BPBD Kabupaten Ponorogo dapat menghasilkan kinerja yang mewujudkan peran dari TRC bekerja di BPBD Kabupaten Ponorogo.

\section{DAFTAR PUSTAKA}

Ajhuri, Kayyis Fithri. Psikologi Perkembangan Pendekatan Sepanjang Rentang Kehidupan. Yogyakarta: Penebar Media Pustaka, 2019. 
Fery Supriyanto, Imelda, dan Sri Gustini. "Pengaruh Motivasi Kerja Terhadap Kinerja Pegawai Badan Penanggulangan Bencana Daerah Kabupaten Musi Banyuasin” Jurnal Manajemen Kompeten Vol. 1 No. 2 Desember 2018, 82 - 97, Sekolah Tinggi Ilmu Ekonomi Rahmaniyah Sekayu, 96.

Hasibuan, Malayu S.P. Manajemen: Dasar, Pengertian, dan Masalah. Jakarta: PT Bumi Aksara, 2016.

Hirnima, Zahra Madina. Studi Deskriptif Dampak Pengembangan Capacity Building Organisasi Pada Tingkat Responsivitas Tanggap Darurat

Bencana di Badan Penanggulangan Bencana Daerah Kabupaten Ponorogo, Artikel Jurnal Ilmu Administrasi Negara dari Universitas Airlangga.

https://bpbd.ponorogo.go.id/profil/ diakses pada Rabu, 4 Maret 2020 pukul 12.12 WIB.

https://bpbd.ponorogo.go.id/regulasi/peraturan-daerah/ diakses pada Rabu, 4 Maret 2020 pukul 12.24 WIB.

https://bpbd.ponorogo.go.id/profil/visi-misi-tujuan-sasaran/ diakses pada Rabu, 4 Maret 2020 pukul 12.13 WIB.

Hurlock, Elizabeth B. Psikologi Perkembangan Suatu Pendekatan Sepanjang Rentang Kehidupan Edisi Kelima. Jakarta: Erlangga.

Iqbal, Muhammad. Psikologi Pernikahan Menyelami Rahasia Pernikahan. Depok: Gema Insani, 2018.

Jadwal Piket Harian Mako Tim Reaksi Cepat (TRC) Dan Pusdalops Badan Penanggulangan Bencana Daerah Kabupaten Ponorogo Bulan Maret 2020.

Karmila. "Kesiapsiagaan Badan Penanggulangan Bencana Daerah Terhadap Penanggulangan Bencana Banjir di Kabupaten Gowa”, Skripsi Mahasiswa Jurusan PMI Konsentrasi Kesejahteraan Sosial Fakultas Dakwah dan Komunikasi Universitas Islam Negeri Alauddin Makassar, tahun 2017.

Moeheriono. Pengukuran Kinerja Berbasis Kompetensi. Jakarta: PT Rajagrafindo Persada, 2012.

Moleong, Lexy J. Metodologi Penelitian Kualitatif. Bandung: PT Remaja Rosdakarya, 2016.

Samsudin, Sadili. Manajemen Sumber Daya Manusia. Bandung: CV Pustaka Setia, 2006.

Soerjono Soekanto dan Budi Sulistyowati. Sosiologi Suatu Pengantar. Jakarta: PT Rajagrafindo Persada, 2015.

Sugiyono. Metode Penelitian Kuantitatif, Kualitatif, dan R\&D. Bandung: CV Alfabeta, 2016.

Pengertian Bencana. Peraturan Kepala Badan Nasional Penanggulangan Bencana Nomor 3 Tahun 2008 Tentang Pedoman Pembentukan Badan Penanggulangan Bencana Daerah, 2. 
Pengertian Bencana, Pengertian TRC BNPB, Pengertian Penilaian Kebutuhan. Peraturan Kepala Badan Nasional Penanggulangan Bencana Nomor 9 Tahun 2008 Tentang Prosedur Tetap Tim Reaksi Cepat Badan Nasional Penanggulangan Bencana.

Pengertian SATKORLAK PB/BPBD Provinsi dan SATLAK PB/BPBD, Peraturan Presiden Republik Indonesia Nomor 83 Tahun 2005 Tentang Badan Koordinasi Nasional Penanganan Bencana.

Tampubolon, Manahan P. Perilaku Keorganisasian (Organization Behavior). Bogor: Ghalia Indonesia, 2015.

Tugas Pokok dan Fungsi TRC. Peraturan Kepala Badan Nasional Penanggulangan Bencana Nomor 9 Tahun 2008 Tentang Prosedur Tetap Tim Reaksi Cepat Badan Nasional Penanggulangan Bencana, 5.

Upah Minimum Kabupaten/Kota di Jawa Timur. Keputusan Gubernur Jawa Timur Nomor 188/568/KPTS/013/2019 tentang Upah Minimum Kabupaten/Kota di Jawa Timur Tahun 2020, lampiran 2. 